Kampala, Uganda

henrywasswa@gmail.com Cite this as: BMJ 2021;374:n1909 http://dx.doi.org/10.1136/bmj.n1909 Published: 9 August 2021

\section{Covid-19: Uganda's low inpatient numbers mask high community infection as desperate patients turn to herbs}

\section{Uganda's second wave seems to be passing after a frantic month. However, high hospital costs and overstretched resources have fuelled a wild west of herbal remedies, reports Henry Wasswa}

\author{
Henry Wasswa freelance journalist
}

One month ago, Uganda was badly hit by the covid-19 delta variant that has been sweeping the world. Ministry of Health figures show that 31635 people had been admitted to Ugandan hospitals with covid-19 by 9 July.

"The situation is stabilising but we have lost a lot of people," says Charles Kasozi, proprietor of the Saint Anthony Polyclinic just outside the capital, Kampala. "We have had a lot of covid patients in all stages; mild and severe during this second wave but now the cases are declining due to the effects of the lockdown."

Kasozi's clinic handled over 20 new patients with covid-19 each day during the first weeks of a 42 day lockdown imposed on 18 June. The facility is now almost empty. Behind fading green curtains, the nurses and laboratory assistants seemed relaxed, sipping tea while conversing with their outpatients.

But this hospital scene does not reflect the true state of the pandemic in Uganda. Thousands or tens of thousands of other Ugandan covid-19 patients are believed to have opted to seek treatment from home to dodge the high fees charged by hospitals.

"Many patients have been at home, sick and dying there without going to hospital," Kasozi says. "They heard from radios that the hospital bills were ten, twenty or fifty million shillings. And the pandemic was so big, patients were so many and the system was overstretched. People are taking herbs as a result."

The country has been awash with daily reports of recovering patients being detained by hospitals for failure to pay millions of shillings in treatment charges and even dead bodies being retained by health centres after relatives failed to clear the unpaid bills.

\section{Desperate times}

At the time of writing, the total number of confirmed covid-19 cases in Uganda stood at nearly 93000 , with over 2500 deaths, 1629 of which were recorded between 7 June and 7 July.

Before the second wave hit the country, there was a general laxity among the population. Reports of deaths from covid-19 were sparse and few people wore face masks, as much of the continent escaped the scenes seen elsewhere in the world during 2020.

"People did not know that covid-19 was real and were mocking the government for the lockdown," says Stephen Epajjar Ojulu, a retired anthropologist formerly of Uganda Christian University. "They did not care and thought the disease was a myth. They [only] realized that it was real when everybody suddenly got infected and they started losing dear ones.”

By mid-June, when numbers of people getting infected with covid-19 were rising fast during the second covid-19 wave, Uganda faced an acute shortage of oxygen and there were daily reports of people dying as they waited for oxygen cylinders in hospitals. The Ugandan government appealed to neighbouring countries for urgent supplies, with canisters eventually imported from Kenya with the help of the World Health Organization.

The sense of panic was escalated by the lack of beds in hospitals at the height of the epidemic and media coverage of the high medical fees.

\section{Desperate measures}

Ugandans have rushed to protect themselves in any way they could. Between 15 May and 18 June at least 800 people were injected with counterfeit drugs, according to government officials.

"We arrested two people while another, who is a physician, supposed to treat people, is still on the run," says Warren Namara, head of the covid-19 health monitoring unit set up by the government, "People were given fake drugs by these people and we are still investigating."

Others have taken or smeared or steamed themselves with herbal leaves, stems, or roots and bought any available manufactured herbal drugs purporting to treat covid-19.

Stephen Epajjar Ojulu is one of them. When his 47 year old wife caught covid-19 recently he says he used eucalyptus tree leaves, onions, garlic, mango leaves, and other herbs in various combinations. "We did not take her to hospital. We used modern medicine (the antibiotic azithromycin as well as vitamin $\mathrm{C}$ and zinc supplements) along with [the] herbs,” Ojulu says.

Mukuza Muhereza, secretary general of the Uganda Medical Association, says that while herbal preparations can have a soothing effect and offer relief for some ailments such as a sore throat, they can also be dangerous. Some people take large doses that the body struggles to process. "Herbalists are telling people that they can drink the drugs as much as possible and these drugs have inflicted injuries either to the liver or the kidneys. What we are seeing are cases of liver and renal damages emanating from prolonged and probably from indiscriminate dosing." 
One product particularly in demand is a herbal supplement called Covidex, developed by a professor from the state owned Mbarara University of Science and Technology.

"When people had heard about it, they went and stocked [up on] it as if they were buying salt," says Muhereza, "This and other drugs like azithromycin and vitamins ... we strongly denounce, especially [Covidex] which has very very serious effects and we have [expressed our] views to the ministry that makes [the] guidelines.

"People grew up in the villages where the cure for ailments were leaves, roots and branches of trees and herbs," he adds, "The herbal guys are now exploiting the [covid] situation."

\section{Questionable approvals}

Surprisingly, Covidex is officially approved by Uganda's drug regulator, the National Drug Authority (NDA), even though, says Muhereza, it has never gone through a clinical trial.

NDA spokesperson Abiaz Rwamwiri says that they granted a notification to the manufacturers of Covidex "as a supportive treatment in the management of viral infections after scientifically all formations and composition data, laboratory report and after conducting an audit of the factory for good manufacturing practices" (sic).

Rwamwiri told The BMJ that at least four other herbal drugs are being developed by state backed scientists in Uganda but have not yet been approved. One group, who are developing Covilyce-1, has been reprimanded by the NDA for carrying out tests in patients before applying to the NDA for testing approval.

But none of these remedies has gone through clinical trials, say the Uganda Medical Association. Muhereza says the association "requests the NDA to investigate safety, specifically for Covidex and this includes its use over ages from the very young and the very old, those with suspected renal issues, those who could be having liver problems and the drug's interaction with other drugs.”

He says a related problem is that manufacturers are allowed to advertise their products indiscriminately, which leads people to take these products in dangerous quantities.

Kasozi says patients must realise that while traditional treatments are readily available, they are not a treatment for the real covid-19 infection.

"Someone with mild covid-19 can recover without any drugs. So people who recover with herbs would have recovered without going to hospital," Kasozi told The BMJ. "People who suffer consolidated lungs, pneumonia or low oxygen circulation cannot recover using herbs. They need modern drugs, not herbs."

\section{Vaccines to the rescue}

A national vaccination drive is under way, but so far just 1087152 have been vaccinated out of a targeted 21.9 million adults (the ministry says 880 ooo have received at least one dose). Uganda's population is over 44 million.

Hundreds of thousands of covid-19 vaccine doses are being transported around the country throughout July, including 650 ooo doses of the Pfizer vaccine from the WHO's Covax scheme. Another 880 ooo AstraZeneca doses are expected from Covax before the end of the month, along with a Chinese donation of 300 ooo doses of Sinovac during the same period.

Although infection rates and deaths have started falling, Namara told The BMJ that it's too early to celebrate. "We should now look into the future as we expect another wave."
Competing interests: I have read and understood BMJ's policy on declaration of interests and have no relevant interests to declare.

Provenance and peer review: Commissioned; not externally peer reviewed.

This article is made freely available for use in accordance with BMJ's website terms and conditions for the duration of the covid-19 pandemic or until otherwise determined by BMJ. You may use, download and print the article for any lawful, non-commercial purpose (including text and data mining) provided that all copyright notices and trade marks are retained. 